5. Довженко О. П. Вибрані твори / О. П. Довженко. - Одеса : Маяк, 1976. - 147 с.

6. Зеленин Д. К. Табу слов у народов Восточной Европы и Северной Азии / Д. К. Зеленин // Сб. музея антропологии и этнографии. $-1930 .-$ Т. IX. -164 с.

7. Зборовська Н. Українська реконкіста : [антироман] / Н. Зборовська. - Тернопіль : Джура, 2003. - 304 с.

8. Мирний П. Твори : у 2 т. / Панас Мирний. - Т. 1 : Оповідання. Повісті. Романи. Драматичні твори (1872-1898). - К. : Наук. думка, 1989. - 752 с.

9. Прислів'я та приказки : Взаємини між людьми / [упоряд. М. М. Пазяк]. - К. : Наук. думка, 1991. - 440 с.

10. Северинюк В. М. Тематичний словник популярних українських прислів'їв та приказок / В. М. Северинюк. - Тернопіль : Навч. книга - Богдан. - 2014. - 176 с.

11. Словник української мови : в 11-и т. / гол. ред. І. К. Білодід. - К. : Наук. думка, 1980. - T. XI. -699 c.

12. Стельмах М. П. Вибрані твори : у 2 т. / М. П. Стельмах. - Т. 2 : Гуси-лебеді летять. Щедрий вечір. - К. : Український письменник, 2003 - 266 с.

13. Сучасна українська література кінця XX ст. - початку XXI ст. / упоряд. текстів I. М. Андрусяк. - К. : Школа, 2006. - 464 с.

14. Тютюнник Г. М. Твори. Оповідання / Г. М. Тютюнник. - К. : Молодь, 1984. -328 с.

15. Українка Л. Вибрані твори : поезії ; поеми ; драматичні твори / Леся Українка. - К. : Дніпро, 1974. - 630 с.

16. Українські прислів'я і приказки / уклад. М. Номис. - К. : Либідь, 1993. - 768 с.

17. Франко I. Зібрання творів у п’ятдесяти томах / I. Франко. - Т. 14 : Повісті та оповідання (1890-1910). - К. : Наук. думка, 1978. - 485 с.

18. Хомік О. Є. Український вербальний оберег : семантика і структура : автореф. дис. ... канд. філол. наук / О. Є. Хомік. - Х., 2005. - 22 с.

Стаття надійшла до редакиії 06.10.2017 p.

I. В. Житар, Т. А. Давиденко

\title{
ФУНКЦІОНУВАННЯ НОМІНАТИВНИХ ВСТАВЛЕНИХ РЕЧЕНЬ У ТЕКСТАХ НАУКОВОГО І ПУБЛІЦИСТИЧНОГО СТИЛІВ УКРАЇНСЬКОЇ МОВИ
}

Житар І. В., Давиденко Т. А. Функціонування номінативних вставлених речень у текстах наукового і публіцистичного стилів української мови.

У статті досліджено функціонування в текстах наукового і публіцистичного стилів номінативних вставлених речень (ізольовані в межах базового речення конструкції, що являють собою субстантиви в називному відмінку або поширені конструкції зі стрижневим субстантивом у називному відмінку). Проілюстровано, що номінативні вставлені речення в науковому і публіцистичному стилях можуть вносити до базового речення такі констатувально-уточнювальні значення: констатація наявності суб'єкта дії; констатація наявності ознаки; констатація локальності. Функцію 
стрижневого номінативного компонента може виконувати й одиниця 3 числовою семантикою; досить часто номінативні вставлені речення вжиті для ідентифікації певного іншотекстового фрагмента.

Ключові слова: вставлені конструкції, номінативні речення, номінативні вставлені речення, науковий стиль мови, публіцистичний стиль мови.

Житарь И. В., Давиденко Т. А. Функционирование номинативных вставных предложений в текстах научного и публицистического стилей украинского языка.

В статье исследуется функционирование в текстах научного и публицистического стилей украинского языка номинативных вставных предложений (изолированных в рамках базового предложения конструкций, которые являют собой субстантивы в именительном падеже или распространенные конструкции со стержневым субстантивом в именительном падеже). Акцентируется внимание на том, что номинативные вставные предложения в текстах научного и публицистического стилей могут вносить в базовое предложение такие уточняющие значения: констатация наличия субъекта действия; констатация наличия признака; констатация наличия локальности. В роли стержневого номинативного компонента может быть единица с числовой семантикой; очень часто номинативные вставные предложения употреблены для идентификации фрагмента чужого текста.

Ключевые слова: вставные конструкции, номинативные предложения; номинативные вставные предложения; научный стиль; публицистический стиль.

Zhytar I. V., Davydenko T. A. The Functioning of Nominative Parenthetic Sentences in the Scientific and Journalistic Styles of Ukrainian Literary Language.

In the paper the functioning of nominative parenthetic sentences in the scientific and journalistic styles is analyzed. The authors have nominated them as syntactical isolated constructions of the basic sentence. These items are both substantives in the Common Case and complicated constructions with basic substantive in the same Case. Ukrainian linguists establish the fact of various usages of these constructions, their peculiarities greatly concerned with affirmation establishing items or phenomena existence. But their distinctive feature means understanding them as a part of the Present Tense because of the absence of syntactical verbs constructions used in special tenses or verbs voice. The paper shows that the nominative parenthetical sentences have the similar usage as nominative ones, e.g., in the limits of basic sentence they transform the data with the statement of available necessary items, but they must be followed by the detailed feature. Nominative sentences predication is illustrated by affirmation intonation.

The authors have determined that nominative parenthetic sentences in the scientific and journalistic styles of Ukrainian literary language may give additional, exact functions to the basic sentence as follow: 1) affirmation about the subject of some activity (nominative parenthetic sentence names the performer, in the basic sentence it is called partly); 2) affirmation about the feature existence (nominative parenthetic sentence names the feature, with the feature so characteristic of the basic sentence); 3) local affirmation (nominative parenthetic sentence points to the component of basic sentence location). The main nominative component function can be performed by an item with numeral meaning. Nominative parenthetic sentences are often used both in journalistic and scientific texts to the identification of another text portion, especially for the identifications the text with its author (identification feature) or with the source of other text. 
The paper shows that the structure of nominative parenthetic sentences is the substantive lexical words in the basic form or the construction with the basic substantive in the Common Case.

Key words: parenthetic constructions, nominative sentences, nominative parenthetic sentences, scientific style, journalistic style.

У текстах наукового і публіцистичного стилів функціонують вставлені конструкції, що являють собою субстантиви в називному відмінку або поширені конструкції зі стрижневим субстантивом у називному відмінку. Такі синтаксично незалежні слова та словосполучення, як стверджує І. Щоболєва (дослідниця виділяє їх в один із двох класифікаційних різновидів вставлених одиниць на противагу оформленим як члени речення або частини складного речення), у російській мові найменш уживані [9, с. 102]. В українській мові мовознавці констатують факт їхньої значної поширеності, а самі одиниці кваліфікують як номінативні речення [6, с. 398]. Односкладні номінативні речення - синтаксичні конструкції, специфіка яких полягає у ствердженні буття предметів чи явищ. Головний член таких конструкцій виражений субстантивом у формі називного відмінка. Відмінною рисою цих одиниць $є$ те, що їх сприймають у площині синтаксичного теперішнього часу через відсутність дієслівних засобів вираження граматичних значень часу і способу.

На наявність у межах структури простого ускладненого речення вставленого номінативного речення вказував ще Л. Булаховський, зокрема на наявність у реченні називного відмінка, імені, що $\epsilon$ граматично не пов'язаним із реченням компонентом (у реченні він не виконує жодної синтаксичної функції). Дослідник зазначав, що вони зазвичай вживаються як самостійні центри речення. Незважаючи на походження цих самостійних одиниць, у реченні вони сприймаються як уламки іншого речення, вставлені в основне речення, хоч інтонаційно вони можуть і не виділятися. Якщо ж інтонаційне виділення наявне, такі компоненти починають наближатися до вставних речень (мовознавець не розмежовує вставні та вставлені I. Ж., Т. Д.), які являють собою вже справжні речення, не пов'язані 3 основним реченням, а впроваджені в нього або додані до нього чи то задля виділення якоїсь деталі, чи то обгрунтування його загалом або в частині, чи то висловлення ставлення мовця або встановлення зв'язку 3 попередніми реченнями (або подіями) [4, с. 131-132].

А. Шапіро також розглядав вставлення, що мають форму -337- ○І. В. Житар, Т. А. Давиденко, 2017. 
номінативного речення, і зараховував речення 3 ними до великої класифікаційної групи речень, де вставлені конструкції синтаксично не пов'язані з базовим реченням [7, с. 308].

А. Прияткіна констатує наявність у реченні синтаксично ізольованих частин (слово, група слів чи речення), які можуть являти собою субстантивну групу в називному відмінку або бути самостійною в плані форми предикативною конструкцією [5, с. 158]. Отже, на те, що вставлені речення можуть бути оформлені як номінативні речення, дослідники вказували досить давно. Проте самостійним об'єктом наукових досліджень ці одиниці ще не були. Це і зумовлює актуальність нашої наукової розвідки. Мета статті - дослідити особливості функціонування вставлених номінативних речень, їхнє призначення та структурні особливості на матеріалі текстів публіцистичного та наукового стилів сучасної української літературної мови.

Як відомо, призначенням номінативних речень $є$ передавання констатувального значення буття предмета, ствердження буттєвості предмета або його образу [3, с. 125]. Ю. Шерех зазначає, що номінативні речення «відповідають тому особливому характерові мислення, коли людина просто фіксує свої враження, свої спостереження, не дбаючи зараз про об'єднання їх в одне ціле, не встановлюючи між ними зв'язків, підлеглости або взаємозалежности» [7, с. 95-96]. Предикативність у номінативних реченнях виражається інтонацією констатації [1, с. 184]. Семантичною спеціалізацією речень цього типу є ствердження буття (наявності, існування) предметів або явищ [2, с. 178].

Номінативні вставлені речення мають аналогічне призначення: у межах базового речення вони передають інформацію із семантикою констатації наявності відповідних предметів, проте вона обов'язково супроводжується уточнювальним відтінком: Ритуал ініціащіï, щио виник у примітивному суспільстві, фрагментарно зберігся в Украйні до XXI століття (соціалізація сільської молоді, армійські ініціації) (1, с. 2); Прошу тебе, негайно вилітай до Москви, візьми з собою Апанасенка (генерал армії, командувач Особливого далекосхідного військового округу), умов бути податливим, щяоб не пручався, я його впертість знаю $(4$, с. 51). Отже, номінативні вставлені речення структурний елемент речення 3 позаграматичним статусом, який вносить до основної частини на рівні всього іiі змісту чи змісту іiі складових додаткові уточнення щодо констатації наявності ๑ І. В. Житар, Т. А. Давиденко, 2017. 
відповідних предметів, що допомагає адресатові сприйняти передану думку відповідно до комунікативних намірів іiі автора; мають інтонаційну та пунктуаційну відокремленість від базового речення; не передають модальну та прагматичну інформацію; виражені субстантивом у називному відмінку або поширеною конструкцією зі стрижневим субстантивом у називному відмінку.

Номінативні вставлені речення у науковому та публіцистичному стилях можуть вносити до базового речення такі констатувальноуточнювальні значення:

1) констатація наявності суб'єкта дії:

Номінативне вставлене речення називає діяча, про якого в базовому реченні повідомляється тільки контурно: У цุей день поминали покійних родччів, прибирали зеленню їхні могилки, клали на них частування, звертаючись до них, як до живих, оплакували, голосили (старші, одружжені жінки) (5, с. 27);

2) констатація наявності ознаки:

Номінативне вставлене речення називає ознаку, якою наділено компонент базового речення: Дисертант пропонує узагальнене розуміння етнічної ідентичності як засобу виділення й віднесення людиною $i$ групою себе чи інших осіб за певними ознаками (усвідомлення своєї єдності, спільності походження, історичної долі, культури, комплекс стереотипів свідомості й поведінки) до певної етнічної спільноти (2, с. 52);

3) констатація локальності:

Номінативне вставлене речення вказує на локалізацію компонента базового речення: $У$ день місиевого самоврядування $у$ школі № 199 Шевченківського району було відкрито новий спортивний комплекс (вул. Бакинська, 12) (3 газети).

Речення, що репрезентують цей різновид, найбільш поширені в текстах наукового й публіцистичного стилів.

Функцію стрижневого номінативного компонента виконує й одиниця з числовою семантикою: Парламент таки проголосував за те, щуоб наступний тиждень не був пленарним (понад 300 депутатів) (3 газети).

Досить часто номінативні вставлені речення вжиті в публіцистичному і в науковому тексті для ідентифікації певного іншотекстового фрагмента, наприклад:

-339- ㅇ․ В. Житар, Т. А. Давиденко, 2017. 
1) 3 його автором. Це може бути:

а) безпосередня вказівка-ідентифікація: Було б вкрай нерозумним вважати, щчо з початком перепроектування сочіальної політики треба чекати того моменту, коли «наростаюча хвиля перекине всі човни» (Конфуцій) (3 газети); "Народи, серед яких жиди живуть, усі разом і кожен зокрема, - явні чи приховані антисеміти» (Теодор Герцль) (6, с. 110);

б) вказівка, опосередкована ідентифікаційним кваліфікатором: $A$ це можливо за умови «співпереживання» (термін Арс. Тарковського) перекладача, щзо сприяє і його самовираженню, $і$ становленню нового тексту (3, с. 87); Першим був зухвалий «темный малороссийский учитель» (вираз Тургєнсва) Микола Гоголь, котрий вніс у літературу струмінь християнського проповідництва - $і$ наштовхнувся на глуху стіну нерозуміння (6, с. 123-124);

2) із джерелом іншотекстовості: У нас неможлива поява позитивної історії релігї і теології - такої, яка вийшла в Любліні 1988 року (Софія Й. Здебіцька, "Релігія і релігієзнавство») (6, с. 91); «...3а n'ять хвилин бомбардувальники США потопили всі чотири грізні японські авіаносціџ (ж. "Америка», 1985, вересень, № 346, с. 3) (4, с. 58); I події в місті Яворові («Імпічмент» із продовженням, «МіЛ» № 6 (7), квітень, 2009) привернули увагу газети лише тому, шзо боротьба навколо посади мера набрала потворних форм: у хаосі тих подій місиева мерія нагадувала химеру з кількома «головами» (3 газети).

Номінативні вставлені речення можуть бути:

а) однослівними (власні та загальні назви): ... запрограмоване нав'язування цьього комплексу проводилося з боку «надлюдини» (Гітлер) або ідеологів наростання класової боротьби (Сталін), щзоб створити вищі раси (обрані народи, класи, партіі) ... (4, с. 9 );

б) поширеними структурами: Так, фундаторами нових містечок на цій території були: переселенці із Середньої Наддніпрянщини (Білолуцьк, Закотне Новопсковського району), з Правобережной України (Шульгинка Старобільського району), Східного Полісся (Біловодськ), жителі Західної Слобожанщини (Коломийчиха, Мілуватка Сватівського району)... (7, с. 47); За підсумками переговорів в Баку, «Газпром» також був включений в список пріоритетних покупців азербайджанського газу з другої черги найбільшого родовища «Шах-Деніз» (запаси більще 1,2 трильйонів кубометрів) (3 газети).

(ㄱ.І.В. Житар, Т. А. Давиденко, 2017. 
Отже, вставлені конструкції, що являють собою субстантивні лексеми в початковій формі або поширені конструкції зі стрижневим субстантивом у називному відмінку, мають статус номінативного вставленого речення, оскільки в межах базового речення вони передають інформацію із семантикою констатації наявності відповідних предметів, проте ії супроводжує уточнювальний відтінок. У публіцистичному та науковому стилях сучасної української літературної мови такі конструкції вживають для передавання констатувального значення буття предмета, зокрема констатації наявності суб'єкта дії, констатація наявності ознаки, констатація локальності.

\section{Література}

1. Валгина Н. С. Синтаксис современного русского языка / Н. С. Валгина. - М. : Высшая школа, 1977. - 440 с.

2. Вихованець I. Р. Синтаксис / I. Р. Вихованець // Граматика української мови / І. Р. Вихованець, К. Г. Городенська, А. П. Грищенко. - К. : Рад. школа, 1982. - С. 133-208.

3. Каранська М. У. Синтаксис сучасної української літературної мови : [навч. посібник] / М. У. Каранська. - К. : Либідь, 1995. - 312 с.

4. Курс сучасної української літературної мови. Т. ІІ. Синтаксис (1. Просте речення, 2. Складне речення, 3. Пунктуація) / за ред. Л. А. Булаховського. - К. : Рад. школа, 1951. $-408 \mathrm{c}$.

5. Прияткина А. Ф. Русский язык : синтаксис осложненного предложения : [учеб. пособие] / А. Ф. Прияткина. - М. : Высшая школа, 1990. - 176 с.

6. Слинько I. І. Синтаксис сучасної української мови : проблемні питання I. І. Слинько, Н. В. Гуйванюк, М. Ф. Кобилянська. - К. : Вища школа, 1994. - 668 с.

7. Шапиро А. Б. Современный русский язык : пунктуация / А. Б. Шапиро. - М. : Просвещение, 1966. - 296 с.

8. Шерех Ю. Нарис сучасної української літературної мови / Ю. Шерех. Мюнхен : Молоде життя, 1951. - 406 с.

9. Щеболева И. И. Структурные типы вставных конструкций в современном русском языке / И. И. Щеболева // Вопросы синтаксиса современного русского языка. - Ростов-на-Дону, 1971. - С. 101-113.

\section{Список джерел ілюстративного матеріалу}

1. Андреєва Т. М. Поетика ініціаційного простору в українському фольклорі : автореф. дис. ... канд. філол. наук / Т. М. Андреєва. - К., 2009. - 19 с.

2. Вільчинська I. Ю. Етнічна та національна ідентичність сучасної української молоді : автореф. дис. ... канд. політ. наук / І. Ю. Вільчинська . - К., 2002. - 20 с.

3. Мовчан П. М. Мова - явище космічне : есе, літературно-критичні статті / М. П. Мовчан. - К. : «Просвіта», 1994. - 168 с.

4. Моргун Ф. Т. Сталінсько-гітлерівський геноцид українського народу: факти i наслідки / Ф. Т. Моргун. - [4-е вид., перероб. і доп.]. - Полтава : Дивосвіт, 2008. - 296 с.

5. Орел Л. Україна в обрядах на межітисячоліть / Л. Орел - К. : ПП «Верещинські», -341- О І. В. Житар, Т. А. Давиденко, 2017. 
2001. $-280 \mathrm{c}$.

6. Сверстюк Є. Блудні сини України / Є. Сверстюк. - К. : Знання, 1993. - 256 с.

7. Ужченко В. Д. Східноукраїнська фразеологія : [монографія] / В. Д. Ужченко. Луганськ : Альма-матер, 2003. - 262 с.

Стаття надійшла до редакиії 02.10.2017 p.

УДК 811.161.2'36

С. Є. Ігнатьсва

\section{МЕТАФОРИЧНІ МОДЕЛІ ПАМ'ЯТІ В УКРАЇНСЬКОМУ ЩОДЕННИКОВОМУ ДИСКУРСІ}

Ігнатьєва С. С. Метафоричні моделі пам'яті в українському щоденниковому
дискурсі.
У статті представлено метафоричні моделі пам'яті як найпродуктивніші в українському щоденниковому дискурсі. Визначені метафори пам'яті окреслено особливими маркерами, що не лише увиразнюють щоденникову текстову тканину, а й формують іï скелет. Виразними вербалізаторами в метафоричній моделі пам'яті названі такі фрейми: «душа пам'ятає», «мати перед очима»; «стояти перед очима», «вертатися думками», «постати перед нею», «спливати в пам'яті». «змигнуги в пам’яті», «не виходити 3 пам'яті», «політати думками понад бідною Україною», «озватися звідти, 3 дитинства, юності», «не запектися в душі», «міцно врізатися в пам'ять», «увібрати в душу, запам'ятати, зберегти у пам'яті», «пропливати перед очима», «зринати з глибин пам’яті», «зостатися в душі», «лягати на душу як тиха молитва», «оживати в пам'яті», «не вмерти в мені», «оновлювати в пам'яті», «зберегти хвилюючі таємниці», «скресають згадки» та ін.

Виокремлено метафоричні образи-порівняння «пам'ять - свічка», «пам'ять рослина», що становлять опозицію за лінією абстрактне - конкретне. Зафіксовано ознакові й адвербіальних метафоричні моделі на позначення процесів пам'яті. Пам'ять - це суперечливий процес спілкування Ego з собою, зі своїм минулим, що постійно дистанціюється. Метафоричну модель пам'яті в щоденниковому дискурсі варто формувати, ураховуючи такими ментальними поняттями, як думка, гадка, свідомість, бажання, сумнів.

Ключові слова: метафорична модель пам'яті, щоденниковий дискурс, метафори пам'яті, метафоричні образи-порівняння.

Игнатьева С. Е. Метафорическая модель памяти в украинском дневниковом дискурсе.

В статье исследуются метафорические модели памяти как самые продуктивные в украинском дневниковом дискурсе. Выделенные метафоры памяти очерчиваются особенными маркерами, которые не только делают выразительными дневниковую текстовую ткань, но и формируют ее скелет. Выразительными вербализаторами в метафорической модели памяти называются такие фреймы: «душа помнит», «иметь перед глазами, «стоять перед глазами», «возвращаться мыслями», «встать пред ней», «сплыть в памяти», «смигнуть в памяти», «не выходить с памяти», «полетать мыслями над бедной Украиной», «озваться оттуда, с детства, с юности», «не запечься в душе», (ㄷ. С. Є. Ігнатьєва, 2017. 